\title{
(Bio)Social Collectives and Social Media: Acid Attack Survivors in India
}

\author{
Kanika Sharma
}

\begin{abstract}
With the increase in social media usage in contemporary times, there is formation of new collectives and identities. Social media had been trending due to its influence and reach in the community creating a space for the 'voice' for many disadvantaged groups. With the help of Paul Rabinow's concept of biosocialities, this study had identified certain collectives and their networks of acid attack survivors. In-depth interviews were conducted with survivors, civil society members and surgeons. Narrative analysis was done to understand the negotiations of survivors for their self and to form their collectives such as advocacy groups, interest from international communities and advancements in medical techniques.
\end{abstract}

Keywords: acid attacks, social media, biosocial groups, Rabinow, collectives.

\section{INTRODUCTION}

In contemporary times, social media is being extensively utilised for the portrayal of one's identity. As the identity formation occurs so does the alignment of their priorities in the social networks. Due to the formation of networks there is a rapid exchange of information (Lopes 2014) resulting in the formation of collectives for one or more cause. Social media has become the platform for various social movements due to its low cost and easier access in mobilising people within and across borders. Stop Acid Attacks is classified as one of those movements where social media had played pivotal role in providing the 'space' for the voice of acid attack survivors.

The idea of doing research on acid attacks came when I read a newspaper clipping that narrated the case of a woman attacked with acid just in front of her house by two assailants in the posh area of Delhi. The work on this area began seven years back but was not able to do at that time due to lack of cases and tracing of the same was very difficult. But cases were sporadically making headlines. I began the search for relevant primary source materials, contacted the survivors and started participating in campaigns. At that time there was only one organisation working on acid attacks which was limited to Karnataka - the Campaign and Struggle against Acid Attacks on Women (CSAAAW) situated in Bangalore. I contacted them and requested a meeting. They described to me their collective attitude towards this dreadful crime and the formation of their organisation. I started searching for someone who would be working on this issue in the city. The search began on internet and social media. There were a few communities formed on social media at that time and that too no one was doing any ground work. After searching for few months a name popped out, a person who wanted to write a book on acid attack and the survivors. I contacted this person by e-mail and asked about his experience. He told me about the acid attack that happened nearby his place in U.P. and that he was following the case. He came in contact with other survivors.

The CSAAAW organization was restricted to the area of Karnataka only and didn't have their website. They were localized to a place where they can physically reach. On the other hand, the search for more and more cases and contact persons begin on the social media platform.

We kept contact over phone and one day invited me to meet an acid attack survivor who was admitted in Safdarjung Hospital (which is nearby my place). Then in the evening I and my mother went to the hospital with packed dinner for them. It was the first time I met an acid attack survivor face to face! Before meeting her, I used to see photographs of survivors and locate their stories on internet. The survivor (let us call her Anita ${ }^{1}$ had lost her left eye in the attack, her face was uneven with small indents and lips were swollen. She was getting ready for the operation of the lip and to check whether the left eye have any kind of scope for vision. She described to me how the attack happened and her ordeal thereafter. Until then there was no aid from the government or any other authority. Her mother was so anxious about 'her marriage'; she kept on telling us how it would be difficult for her daughter to get a groom.

Very few people knew about Anita and her condition, the anxiety of her mother and the ordeal she faced. At that time, many acid attacks were occurring but no one knew much about them except for the mention in print media. I called the journalist to thank him for helping me to meet Anita. As we were discussing over phone what should be done further as he had already begun his work for the cause by networking and forming community on facebook under the name of 'Stop Acid Attacks'. He wanted to begin through social media. The discussion was fruitful in knowing the intricacies of the need of various resources from financial support, volunteers, space, and the strategy of presentation. The biggest ethical question was, if the campaign itself would lead to more crimes or would it help survivors to defend their rights. With this dilemma the conversation ended.

The protest movements have amplified the potential of social media unveiling the development of collective identities in the digital networks (Tarafdar and Seetharaman 2017). This amplification is due to the easy access, low cost media, high user generated content, connection of like-minded individuals and most importantly, it is not restricted to experts, that is, any individual can share their views (Shaw 2016). The range and outreach of social media led to the inauguration of a website 
(www.stopacidattacks.org/) ${ }^{2}$ on the name of 'Stop Acid Attacks' (SAA) campaign on the International Women's Day ( $8^{\text {th }}$ March) in 2013. But I followed the launch on Facebook as photographs were updated. About five survivors attended the event along with many other people from various backgrounds and few were invited from Kerala, who were artists with special abilities.

Due to the formation of 'facebook' group/community on Stop acid attacks the launch of the website with the same name was possible. The requests for various requirements were posted in the community such as laptops, projectors and even asking for a space for its execution. The individuals who didn't know the path to contribute easily they came forward. Thus for the emergence of such website the first collective was formed for this particular campaign. To understand the dynamics of the identity process as an individual and collective, Paul Rabinow's concept of biosociality is utilized.

\section{BIOSOCIAL COLLECTIVES}

Rabinow propounded the term biosocilaity instead of socio-biology during the commencement of Human Genome Project Initiative (HGPI). This terminology was coined to draft the "re-problematisation of "life"" (Rabinow 2008: 188). In other words, biosociality focuses on the "practices of life as the most potent present as the site of new knowledges and powers" (Rabinow 2005: 182). Foucault in History of Sexuality has described biopower and biopolitics in the last part of the book. For him, biopower consists of anatomo-politics and regulatory controls that is, biopolitics. But in the entire part he has used these two terms (biopower and biopolitics) interchangeably. The metamorphosis of human life has its agency in knowledge/power combination and this change brings all the mechanisms under biopower (Foucault 1978). Therefore, "biopolitics attends to the biological processes of the collective social body" (Weaver 2013: 19). It is the regulation of various life processes like reproduction and sexuality, health and illness, population maintenance and living and working conditions (ibid) within the economic processes (Foucault, 1978). That is, the concept of biopower is the interventions upon the characteristics of human beings, that is individually as well as collectively, as living beings who have a life cycle and collection of these living beings (population) (ibid).

Though the concept of biopower can contribute to the transformations in the government of life and death at the beginning of the twenty-first century, but the contours of "welfare, security, health and hygiene" have changed (Rabinow and Rose 2003: 15). This change was leveled at two lines: one, "at the thinking and acting of population groups and collectivities" and their relations; second, "individualization at biopolitical strategies" (ibid: 15). New configurations of collectivities are evolving alongwith autonomy of individuation to follow their right to health, life in "corporeal and vital terms" (ibid: 16). One of the strategies to biopolitically manage individuals in turn population was normalization.

\subsection{Normality}

With the authority to manage the lives statistical measures were created by medicine, that is, norms to assess individuals (Pylpa, 1998). Power via normalisation mechanism has both the effect of "totalising" as it compels to adhere to norms by managing all facets of life (ibid: 23). The other effect of normalisation is "individualizing", because those who cannot be categorized in the range of being normal are marked as misfit and are targeted with various strategies to neutralize their character of deviance (ibid: 24). According to Foucault, norm acts as the basis of inception, legitimation, multiplication and diffusion of power (Taylor 2011). This power functions by "internalisation of these norms" (Oksala 2011: 89). The biomedical discourse has become one of the key strategies to control and neutralise the deviant ('misfit') to the mainstream society.

\subsection{Pre-Biomedicalisation}

There is a shift from isation medicalisation to isation biomedicalisation (as termed by Clarke et al. 2003) due to the developments and innovations in contemporary biomedicine. Biomedical technologies are embedded in the historical, cultural and political milieu (Lock and Nguyen, 2010). These technologies are meshed within the "sociotechnical systems" and are part and parcel of various institutions that include hospitals, corporates, and the state (ibid: 18). Biomedicine's purpose has been not only to heal people but to move beyond this and improvise "bodies, minds and even society" (ibid: 54). This "increasingly complex, multisited, multidirectional processes of medicalisation that today are being both extended and reconstituted through the emergent social forms and practices of a highly and increasingly technoscientific biomedicine" is termed as biomedicalisation (Clarke et al., 2003: 161-194). The major characteristics of this shift from medicalisation to biomedicalisation are given in table 1 . The table shows the shift in a developed country, that is, United States. Whereas in India, there is an advancement from medicalisation but still has not accepted the biomedicalisation completely. The suspension between these two processes is termed as pre-biomedicalization. This process shares some of the characteristics of both medicalisation and biomedicalization.

Table 1: The shift from Medicalisation and Biomedicalisation

\begin{tabular}{|l|l|}
\hline Medicalisation Control & Biomedicalisation \\
\hline \multicolumn{1}{|c|}{ Transformation } \\
$\begin{array}{l}\text { Institutional proliferation of } \\
\text { expert medical authority into } \\
\text { novel spheres }\end{array}$ & $\begin{array}{l}\text { Proliferation } \\
\text { technoscientific } \\
\text { transformations" of } \\
\text { biomedical } \\
\text { establishments, } \\
\text { infrastructures, } \\
\text { information and clinical } \\
\text { treatment }\end{array}$ \\
\hline
\end{tabular}

Economics: The U.S Biomedical Technoservice Complex Inc. 


\begin{tabular}{|c|c|}
\hline $\begin{array}{l}\text { Biomedical, scientific and } \\
\text { clinical research are } \\
\text { maintained by foundations or } \\
\text { state and results are made } \\
\text { public and accessible }\end{array}$ & $\begin{array}{l}\text { Privatisation for research } \\
\text { grew incorporating } \\
\text { university/industry } \\
\text { association; results are } \\
\text { patented }\end{array}$ \\
\hline $\begin{array}{l}\text { Augment of economic } \\
\text { establishments, rationalization, } \\
\text { multinationals, nationalization }\end{array}$ & $\begin{array}{lr}\text { Also escalation of } \\
\text { economic privatisation, } \\
\text { distribution } \\
\text { globalization }\end{array}$ \\
\hline $\begin{array}{l}\text { ons are physician } \\
\text { nated }\end{array}$ & $\begin{array}{l}\text { Institutions are based on } \\
\text { managed care system }\end{array}$ \\
\hline $\begin{array}{l}\text { Stratification based on ability } \\
\text { to afford the medicalisation: } \\
\text { selective exclusion or } \\
\text { medicalisation }\end{array}$ & $\begin{array}{l}\text { Stratification via stratified } \\
\text { rationalization, dividing } \\
\text { the care according to the } \\
\text { population affordability; } \\
\text { new arrangements for } \\
\text { observation and treatment } \\
\text { on "technoscientific } \\
\text { identities" }\end{array}$ \\
\hline \multicolumn{2}{|c|}{ The Focus on Health, Risk and Surveillance } \\
\hline $\begin{array}{l}\text { Functions by definitions, } \\
\text { prognosis (by screening and } \\
\text { testing), categorisation, and } \\
\text { treatment of illness and } \\
\text { diseases }\end{array}$ & $\begin{array}{l}\text { Acts by definition, } \\
\text { detection, categorisation } \\
\text { and treatment of risks; } \\
\text { "commodification of } \\
\text { health and lifestyles" }\end{array}$ \\
\hline $\begin{array}{l}\text { Health policy as issue } \\
\text { resolution }\end{array}$ & $\begin{array}{l}\text { Health governance as } \\
\text { issue description }\end{array}$ \\
\hline $\begin{array}{l}\text { Organs and cells become the } \\
\text { site of disease } \\
\text { conceptualization }\end{array}$ & $\begin{array}{l}\text { ecules are } \\
\text { neation of } \\
\text { s }\end{array}$ \\
\hline \multicolumn{2}{|c|}{ The Technoscientisation of Biomedicine } \\
\hline $\begin{array}{l}\text { Highly restricted } \\
\text { infrastructures with distinct } \\
\text { physician, clinic and hospital } \\
\text { documentation of patients } \\
\text { (innovations such as } \\
\text { photocopier and fax) }\end{array}$ & $\begin{array}{l}\text { Dissemination } \\
\text { digitized doc } \\
\text { due to inc } \\
\text { cohesive infras }\end{array}$ \\
\hline $\begin{array}{l}\text { Single or case based medicine } \\
\text { and patient information } \\
\text { restricted to local jurisdiction }\end{array}$ & $\begin{array}{l}\text { Evidence-based medicine } \\
\text { with the utilisation of } \\
\text { decision-support } \\
\text { technologies and digitised } \\
\text { patient records in } \\
\text { managed care systems }\end{array}$ \\
\hline $\begin{array}{l}\text { Medical science and } \\
\text { technological involvement } \\
\text { such as antibiotics, cancer } \\
\text { treatments, new reproductive } \\
\text { technologies }\end{array}$ & $\begin{array}{l}\text { Biomedical } \\
\text { technoscioentific } \\
\text { transformations such as } \\
\text { geneticization, } \\
\text { bioengineering, } \\
\text { molecularisation }\end{array}$ \\
\hline $\begin{array}{l}\text { Medical specialisations based } \\
\text { on body components and their } \\
\text { processes of incurring diseases } \\
\text { such as cardiology, neurology. } \\
\text { these are considered to be } \\
\text { omnipresent throughout } \\
\text { populations and practice } \\
\text { milieu. }\end{array}$ & $\begin{array}{l}\text { Medical specialisations } \\
\text { are based on } \\
\text { conglomeration } \\
\text { practices and knowledge } \\
\text { of accompanying different } \\
\text { populations and } \\
\text { categories of science and } \\
\text { technology such as trauma } \\
\text { and prison medicine. }\end{array}$ \\
\hline \multicolumn{2}{|c|}{$\begin{array}{l}\text { Transformations of Information, and the Production and } \\
\text { Distribution of Knowledges }\end{array}$} \\
\hline $\begin{array}{l}\text { Specialised } \\
\text { knowledge confined to its }\end{array}$ & $\begin{array}{l}\text { Diverse genres of } \\
\text { information/knowledge }\end{array}$ \\
\hline
\end{tabular}

production and dissemination $\quad$ which is widely accessible to medical professionals $\quad$ through internet and bookstores

Medical professions begins the Miscellaneous initiated interventions, that is, top-down interventions for instance, approach internet users, customers, health related social movements

\section{Transformations of Bodies and Identities}

\begin{tabular}{|c|c|}
\hline Normalisation & Customisation \\
\hline $\begin{array}{l}\text { Ubiquitous taylorised bodies, } \\
\text { medicines and technologies are } \\
\text { like one for all, that is, one } \\
\text { medicine is beneficial for all }\end{array}$ & $\begin{array}{l}\text { Emphasis is on } \\
\text { individualisation like } \\
\text { customised technologies, } \\
\text { medicines, devices }\end{array}$ \\
\hline $\begin{array}{l}\text { Differentiation from bad and } \\
\text { sick and creating } \\
\text { stigmatisation of conditions } \\
\text { and diseases }\end{array}$ & $\begin{array}{l}\text { Individual and collective } \\
\text { identities due to } \\
\text { technoscientisation }\end{array}$ \\
\hline
\end{tabular}

\section{Source: Clarke et al., 2003}

The characteristics identified in Indian context are: medical enterprise is still physician dominated, that is, doctors control the patient records. Saraswati, ${ }^{3}$ one of the acid attack survivors, lost her medical records. When she went to ask in the hospital for duplicate records, they just gave her the overview of the treatment and the bill. The documents are not available anywhere else except in hospital's records. This is the primary feature of medicalisation but there is also new population-dividing practices (development of dormitory-type, semi-private, private rooms in hospitals), which is a characteristic of biomedicalisation. Some of the hospitals have begun with these kinds of practices so as to provide healthcare. Also depending on the emergence of new technoscientific identities there is stratification of treatment provided. Medical science is still more related to antibiotics, cancer treatments and reproductive technologies than geneticisation, bioengineering, and biotechnologies. $\mathrm{RN}$ requires artificial skin, if the skin is not enough to cover the burn. Artificial skin is a bioengineered product. In India, there are few skin banks in comparison to its demand. The body is considered as universal in medical sciences. If one treatment provides positive outcome on an individual it is applied to all. For instance, RN needs pressure garment to avoid skin contraction after surgery or tissue expanders for extra growth of skin. These devices are prescribed and utilized by them respectively. The burns patient is always classified of stigma as burns is considered as deviation from 'normal'. But there is also rise of technoscientific identities as discussed in biomedicalisation. Due to heterogeneous proliferation of medical information by various mediums, individual and collective identities have started to form in Indian context. RN as an identity is created due to which there is formation of collective identities. This generation of collective technoscientific identities will be understood by utilising the concept of biosocialities by Paul Rabinow (1996: 234-252).

Rabinow has done an ethnographic study of HGPI and focused on the "practices of life" describing the life which was at the molecular level (ibid: 236). He visualized the formation of collectivities formed due to genetics that will 
"cease to be a biological metaphor for modern society and will become instead a circulation network of identity terms ${ }^{4}$ and restriction loci, around which and through which a truly new type of autoproduction will emerge" and for him these new productions and identities are called biosociality (ibid: 241). The next point to identity formation is the dissolution of nature/culture divide (ibid, 1996) as there are transformations in life beyond this binary (Gibbon and Novas, 2003). The main element of biosociality is its heuristic properties that are being described by Gibbon and Novas which reflect "an ethic of experimentation with theory and method in its concerns with describing and analysing the significance of developments in the life sciences across a number of social fields" (ibid: 4).

Following studies shows the co-production of the practice of genomics and life sciences are with the social and cultural dynamics in which biosocialities can be understood. Sahra Gibbons (2003) in the study of breast cancer genetics describes emerging biosocialities of the molecular research for it. She has seen how the BRCA (the name of the gene identified as causing breast cancer) female carrier ${ }^{5}$ is caught in the processes such as fundraising, management of expectations and investments in the scientific endeavour and the way this image of the individual and collective travels from needs, rights, hopes or risks in the temporal terrain (ibid). The activists who are involved in this are still not stabilised due to merger of the advocacy groups (ibid). These bio-social entanglements are dynamic and still in formation (ibid). On the other hand, Elizabeth Roberts (2003) in the same volume describes the limitation of biosociality. She argues that this concept should not be applied until and unless there is no "emergent shift in biological thinking towards the malleable" (ibid: 82). In her context of Ecuador she finds that though introduction of IVF can be called as reproductive modernity (term coined by her) there are no patient advocacy groups to ask for these technologies (ibid). These studies depict the multiplicity of biosociality as a concept.

Here, I would like to situate the formation of biosocial identities of acid attack survivors and the emergence of various advocacy groups and new technologies being developed for the burns as a whole. Acid attack survivors negotiate their identities from being victims to survivors as they go through the various surgeries and their relations with the outside. ${ }^{6}$ The process from being disfigured to RN leads to the conflict with self and her outside.

\section{COLLECTIVES EMERGENCE DUE TO ACID ATTACKS}

There is a construction of an identity of 'Reconstructed Normal' with the advent of biomedicalisation. This medically constructed identity has led to the formation of advocacy groups. Organisations evolved for the sole purpose of addressing this issue and took it forward. These civil society organisations sprouted and brought the attention of public through the use of social media. The communities which were developed on facebook led to launch of the website with the same name, pages were created and special centre evolved for acid attack survivors.
All these developments and influence led to awareness and more reporting and identification of acid attack survivors. Survivors came out of their homes, met other survivors, gave interviews in the media and 'uncovered' their faces. This 'togetherness' in pain and identification of themselves led to the formulation of their own collective. Haraways concept of 'situated knowledges' ${ }^{7}$ describes the partial perspective, the multiplicity of sufferings and knowledges that should be taken into account for feminist form of objectivity (Haraway, 1988). This multiplicity gives the essence of marginalized into the theories which otherwise discuss about certain kind of objectivity.

Due to the prominence of the visibility of the faces TVs and social media, demand for policy changes increased with vigor. Campaigns begin offline as well as online and mixture of both. The online platform change.org forms another platform for the 'voice' to be heard at bigger stage and garner attention. The signatures here represent the online involvement of the people with a cause they could sympathise or empathise and relate to it across the world creating socialities geographically. This geographical uprising of socialities led to a project by UN women Iceland.

After the alleged regulation of acid sale, judgment passed by Supreme Court, online videos were shot namely 'shoot acid'. Users were encouraged to make a video on buy/sale of acid from shops to inquire about the follow up of the SC regulations. Various videos were posted on the social media. Despite so much awareness acid was being sold and no stringent action was taken by the officials.

The most striking effect seen was the uploading of photos as 'selfies' on the acid attack survivors' accounts. The survivors who were afraid to venture out without covering their face, they are now uploading selfies and giving interviews without that cover. To raise fund for various causes, another set of people put in their efforts. Crowdfunding to support acid attack survivors was done online, for instance, on indiegogo. Anyone can donate online who believes in that cause. This elaboration at geographical locations had created much more space for the 'unheard'.

Due to acid attack survivors knowledge regarding first aid was generated. Since very few knew about the first aid for acid attacks. In collaboration with surgeons, this knowledge became part of the mainstream. There were rumors in the social media that acid when thrown on any person should be washed with milk. With the help of surgeon this rumor was clarified and circulated through social media.

\section{CONCLUSION}

The identity shift to reconstructed normal itself shows the presence of dual effect of medicine and the state. One of the characteristics of biopolitics is its productivity which results in resistance. As the RNs are stigmatised and sidelined from the mainstream, they struggle to gain their position in the societal endeavours. This resistance led to the formation of biosocial groups to raise their voices. There was a proliferation of NGOs specifically working against acid attacks and for the rehabilitation of the survivors. There was also a shift in policy changes.

As the time progressed they made themselves comfortable with their reconstructed identity 
and started to voice their ordeal. They gave 'words' to their hardships through the media and other communication channels. They uncovered their face so that society can see their suffering. This uncovering exposed the patriarchal nature of our society. This movement brought in radical changes in the mindset of the society although being 'partially accepted'.

\section{REFERENCES}

1. Butler, J. (1993). Bodies That Matter: On the Discursive Limits of Sex. New York: Routledge Publishers.

2. Foucault, M. (1978). History of Sexuality, Vol. I. New York: Pantheon Books.

3. Gibbon, S. and Novas C. (2008). Biosocialities, Genetics and the Social Sciences. London: Routledge Publishers.

4. Gibbon, S. (2008). "Charity, breast cancer activism and the iconic figure of the BRCA carrier". In Biosocialities, Genetics and the Social Sciences: Making Biologies and Identities, edited by Sahra Gibbon, 1st ed., London: Routledge Publishers.

5. Haraway, D. (1988). "Situated Knowledges: The Science Question in Feminism and the Privilege of Partial Perspective". Feminist Studies, Vol. 14 No. 3, pp 575-599.

6. Lopes, A.R (2014). The Impact of Social Media on Social Movements: The New Opportunity and Mobilizing Structure. Accessed from http://www.creighton.edu/fileadmin/user/CCAS/departments/Political Science/Journal_of_Political_Research_JPR_/2014_JSP_papers/Lo pes_JPR.pdf on 10th March, 2018.

7. Pylpa, J. (1998). "Power and Bodily Practice: Applying the Work of Foucault to Anthropology of the Body". Arizona Anthropologist 13: 21-36.

8. Rabinow, P.(2005). "Artificiality to Elightenment: From Sociobiology to Biosociality". In Anthropologies of Reason, edited by Jonathan Xavier Inda 1st ed. London: Blackwell Publishing.

9. Rabinow, P. (2008). "Afterword: concept work". In Biosocialities, Genetics and the Social Sciences: Making Biologiestnd Identities, edited by Sahra Gibbon, 1st ed. London: Routledge Publishers.

10. Rainbow, P. and Rose, N. (2009). "Thoughts on the concept of biopower today. 2003." Acesso em 5

11. Shaw, A. (2016). Role of Social Media in Social Mobilization (with special reference to Shahbag and Hokkolorob movements. Global Media Journal, 7(1), 1-8.

12. Weaver, J. (2014). " Out of sight, out of mind: keeping Russia closeted: A Biopolitical Analysis of Non-Normative Sexualities in Russia." Master Thesis. Cross Border University.

13. Taylor, D. (2011) (ed.). Michel Foucault: Key Concepts. Jaipur: Rawat Publications.

14. Oksala, J. (2010). "Violence and the Biopolitics of Modernity." Foucault Studies 10: 23-43.

15. Clarke, A. et al. (2003). "Biomedicalization: Technoscientific Transformations of Health, Illness, and U.S. Biomedicine." American Sociological Review 68(2): 161-194. 